\title{
Comparison of Structure and Properties of Differently Treated Illite Clay and Products
}

\author{
Gaida Sedmale ${ }^{1}$, Arturs Korovkins ${ }^{2}$, Olga Mutere ${ }^{3}$, Ingunda Sperberga ${ }^{4}$, Maris Rundans ${ }^{5}$, \\ ${ }^{1,2,4,5}$ Riga Technical University, University of Latvia
}

\begin{abstract}
Summary. The investigation is focused on modification of the structure 2:1 sheet silicates - illite clay by subjecting them to chemical and microbiological impact. It is shown that alkaline activation of illite clay by sodium hydroxide leads to the slight structural changes mainly characterized by water link changes. The effect of bacteria Ps. fluorescens AM PS11on structure changes of illite is small and is influenced on rheology of treated clay.It is shown that the influence of chemical treatment on porosity, bulk density and increase of compressive strength of sintered ceramic samples is notable.
\end{abstract}

Keywords: clay, chemical, biological impact, ceramic.

\section{INTRODUCTION}

Illite clay deposits are widespread and are the most important mineral wealth in Latvia, and can be found at various stratum depths from Cambrian to Quaternary geological periods. For practical use determinant is on the Devonian and Quaternary clays [1].They differ in terms of both chemical and mineralogical composition and are characterised by a wide spectra of various particle dispersion that fall within nano range. The typical clay mineral - illite substance is up to $70-80 \%$ with slight admixtures of chlorites,smectites and kaolinites.The Devonian and Quaternary clays are used for production of conventional ceramic products such as building bricks, blocks, roof tiles, pottery, as well as sorbents. [2]. Moreover they were added in the percentage of $35 \mathrm{wt} . \%$ to a mixture composed of feldspar and quartz sand for the production of stoneware tiles.It is shown [3] that the presence of illite inhibits the formation of mullite and cristobalite, since silica and alumina tend to form alkaline glass. The presence of small amount of goethite in this clay promotes the formation of mullite.

It is known that to the attainment of a final strength at lowered temperatures of an alumosilicate materials it is required the presence of an X-ray amorphous network of aluminium and silicon atoms solely in tetrahedral coordination with oxygen. The ability to attain an increased compressive strength of these materials by proper mix development with activating alkali solution is well documented [e.g. 4-6].

One of more investigated solid alumosilicate under highly alkaline conditions is the 1:1 layer lattice alumosilicate mineral - kaolinite [6].Although the mainly used in the preparation of 1:1 layer lattice alumosilicates, i.e.,geopolymers, it is also of interest $2: 1$ minerals such as $2: 1$ analogue of kaolinite - pyrophillite with unitstructure $\mathrm{Al}_{2} \mathrm{AlSi}_{3} \mathrm{O}_{10}(\mathrm{OH})_{2}$, in which the octahedral $\mathrm{Al}-\mathrm{O}$ sheet isenclosed above and below by two tetrahedral $\mathrm{Si}-\mathrm{O}$ sheets to form a repeating unit [7]. It is shown that attempts to produce fully reacted alumosilicategeopolymers from the crystalline $2: 1$ lattice mineral, pyrophillite, was unsuccessful. Dehydroxylation of pyrophillite at $800^{\circ} \mathrm{C}$ produces significant changes in the $\mathrm{Al}$ coordination, but does not form a viable geopolymer. It was suggested that inability to form viable geopolymers may be due to the retention of the crystalline $2: 1$ layer structure in pyrophillite and its dehydroxylated phase. According to the authors [6] the enclosed $\mathrm{AlO}_{6}$ sheet by the upper and lower $\mathrm{SiO}_{4}$ sheets is protected from alkaline attack to form a soluble aluminate species. It is shown that disruption of the crystalline 2:1 layer lattice by severe mechanochemical ball- or vibro-milling processing enables geopolymeric materials which attain reasonable hardness and strength at $60^{\circ} \mathrm{C}$. These materials were not fully X-ray amorphous, but Xray powders show traces of zeolitic phases.

It [8] is concluded that 2:1 clay minerals such as illite and smectite yield reactive silicate and aluminate species after calcinations. The best performance can be attained by producing fully dehydroxylated clay minerals and preventing the formation of new stable phases such as spinel.

This investigation is focused on modification of the structure of typical 2:1 sheet silicates - illite clay by subjecting them to chemical and microbiological impact in an attempt to change or ruin specific network-forming linkages among Si-O and $\mathrm{Al}-\mathrm{O}$ units and sequentiallyproperties of sintered ceramics.

\section{EXPERIMENTAL PROCEDURE}

The starting materials were the intermediate composition of Quaternary and Devonian clay samples taken (accordingly) in the Laza $(\mathrm{L})$ and Nicgales pits $(\mathrm{N})$ as well as $\mathrm{Kuprava}(\mathrm{K})$ pit from the 2-3m depth of the soil. The first two mentioned clay deposits are formed in the Quaternary deglaciation time of the last glaciation, but Kuprava - in the Devonian time. These clays form national meaning clay deposits and in general have a fair amount of carbonates and high illite clay fraction content. The mean $\mathrm{SiO}_{2} / \mathrm{Al}_{2} \mathrm{O}_{3}$ wt. ratio is 2.45 - 3.10 .

The clay $\mathrm{L}$ was used for chemical as well as for biological treatment, but clays $\mathrm{N}$ and $\mathrm{K}$ - only formicrobiological treatment. Yje supplementary materials for clay chemical treatment were $\mathrm{NaOH}$ pellets for preparation of $1 \mathrm{M}, 3 \mathrm{M}, 4 \mathrm{M}$ and $6 \mathrm{M} \mathrm{NaOH}$-water solutions, as well as bacterium Pseudomonas fluorescens AM-PS11 for biological treatment.

The middle chemical composition and fraction content of these clays are shown in [9].

The raw clay was ground and possible undesirable hard inclusions were separated by screening (Retsch equipment AS200 sieve with aperture $1.0 \mathrm{~mm}$ ) to obtain the clay powder for respective treatment. 
For chemical treatment the alkali solution-clay powder ratio was fixed to $20-23 \%$ alkali solution at clay powder yielding a good workability of the clay. The solution-clay mix was aged for $24 \mathrm{~h}$ at room temperature.

For microbiological treatment the following scheme was used, Figure 1.

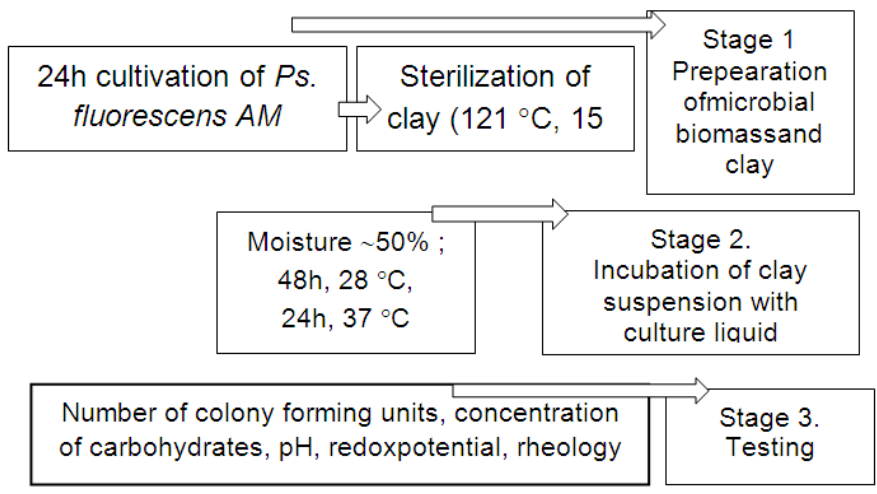

Fig.1.Scheme for microbiological treatment.

Thereafter both chemically and biological treated mixes were investigated by IR-spectroscopy (spectrophotometer IR prestige-21FTIR-8400S) to establish possible changes of the structure,thermal analysis using a Setaram, SETSYS Evolution - 1750 model at temperature ranged from 20 to $1000{ }^{\circ} \mathrm{C}$ and a heating rate $10{ }^{\circ} \mathrm{C} / \mathrm{min}$ in flowing technical air (200 $\mathrm{ml} / \mathrm{min}$ ). X-ray diffraction (XRD-model Rigaku, Japan, with $\mathrm{CuK}_{\alpha}$ radiation at scanning interval from $2 \theta=10 \ldots 60^{\circ}$ and speed $4 \%$ min) to determine the crystalline phase changes both for treated clay mix, and sintered ceramic samples. A standard test for liquid and plastic limits for microbiological treated clay was determined in accordance with ASTM standard D4316-05.

To investigate ceramic properties as well as compressive strength of sintered ceramics, cylindrical samples $(\varnothing-25 \mathrm{~mm}$, $\mathrm{h}-30 \mathrm{~mm}$ ) from each treated mix were formed by using of laboratory extruder. These samples were sintered in laboratory furnace (Nabertherm. HT 16/17) at temperatures 100, 300, 600 and $700{ }^{\circ} \mathrm{C}$ with the temperature growth rate $5-6 \%$ min and the holding time at each temperature for $15 \mathrm{~min}$. Investigation of ceramic properties (total porosity, bulk density) and compressive strength were performed in accordance with European Standards EN LVS 63-01-2001 and EN LVS146172007. For strength measurement Toni-technic model 2020 was used. Three samples were measured for each mixture from where the mean values of strength were calculated.

\section{RESULTS AND DISCUSSION}

\section{A.Characterization of both raw chemically and microbiologically treated clay}

The results of X-ray measurement of chemically by $\mathrm{NaOH}$ treated clays in comparison with untreated clay are shown in Figure 2. There must be noted that changes of crystalline phases intensity for raw clay L by the microbiological treatment are not observed.

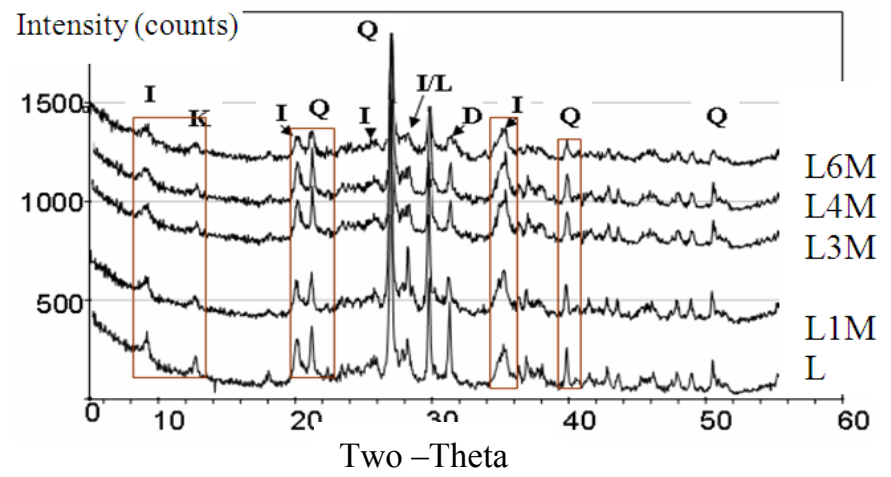

Fig.2. XRD patterns of crystalline phases intensity changes in dependance on concentration of the used $\mathrm{NaOH}$-water solutions: L- untreated raw clay, L1M treated by $1 \mathrm{M} \mathrm{NaOH}, \mathrm{L} 3 \mathrm{M}-$ by $3 \mathrm{MNaOH}, \mathrm{L} 4 \mathrm{M}-$ by 4MNaOH. L6M-by $6 \mathrm{M} \mathrm{NaOH}$.

Crystalline phases: I - Illite $\mathrm{K}(\mathrm{AlFe})_{2} \mathrm{AlSi}_{3} \mathrm{O}_{10}(\mathrm{OH})_{2} \cdot \mathrm{H}_{2} \mathrm{O} ; \mathrm{K}$ Kaolinite $\mathrm{Al}_{2} \mathrm{Si}_{2} \mathrm{O}_{5}(\mathrm{OH})_{4} ; \mathrm{Q}$ - Quartz $\mathrm{SiO}_{2} ; \mathrm{L}$ - Microcline or Ortoclase $\mathrm{KAlSi}_{3} \mathrm{O}_{8} ; \mathrm{C}-$

Calcite $\mathrm{CaCO}_{3} ; \mathrm{D}$ - Dolomite $\mathrm{CaMg}\left(\mathrm{CO}_{3}\right)_{2}$

As it is shown in the alkali activation process of 2:1 illite clay L the reflexes of clay minerals - illite and kaolinite become weaker, but there cannot be observed its disappearance,.i.e., ruining of its structure. The same can be observed also for reflexes of quartz and dolomite.

the thermal analysis results of both chemically and microbiological treated clay as well as untreated clay are shown in Figures $3 a$ and $b$.
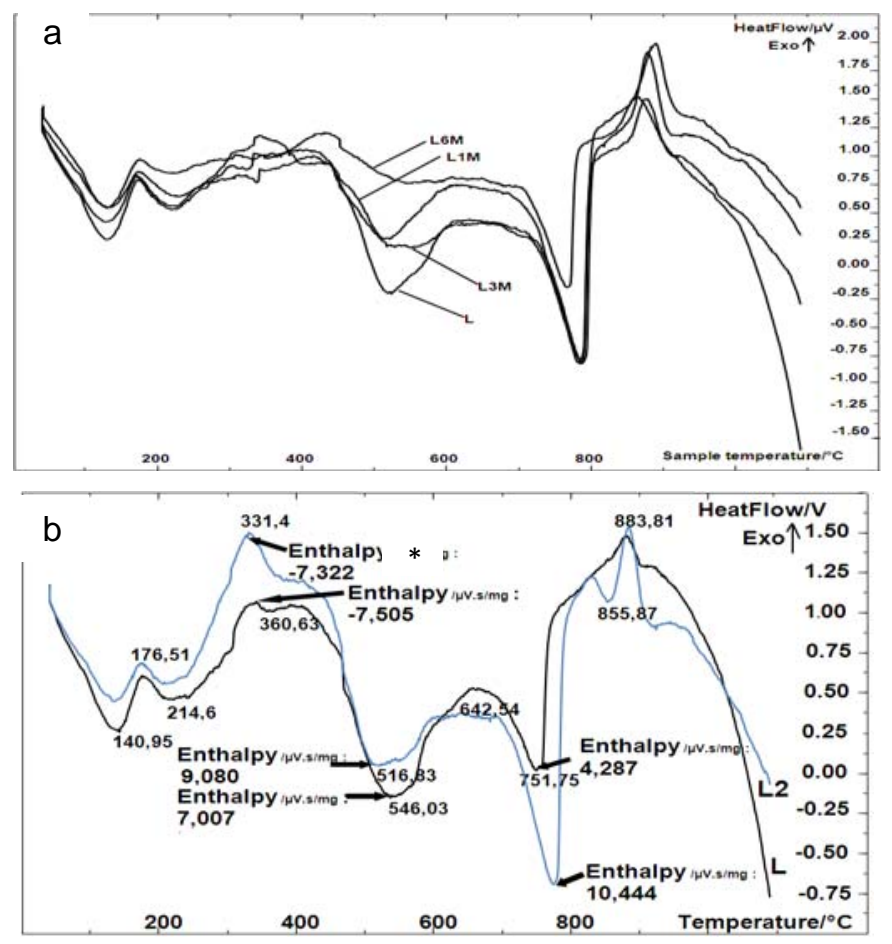

Fig. 3. DTA curves for: a - chemically untreated clay L and treated by $1 \mathrm{M}$, $3 \mathrm{M}$ and $6 \mathrm{M} \mathrm{NaOH}$-water solution; b - microbiologically treated by bacteria Ps. fluorescens AM PS11: L - not treated, L2 - treated for $48 \mathrm{~h} .{ }^{*}$ - enthalpy unit of measurement for all points is $\mu \mathrm{V} . \mathrm{s} / \mathrm{mg}$.

It can be seen that chemically treated clay with growing concentration of $\mathrm{NaOH}$ solutions show a well pronounced and decreasing endo - effect at $510-535^{\circ} \mathrm{C}$. It is connected with 
illite structural water loss and weakening of illite structure. That also is confirmed with the XRD - diffraction reflexes of illite become weaker.

For treated with bacteria Ps. fluorescens AM PS11 these changes are insignificant. Effect of bacteria mainly appears only at about $330-360^{\circ} \mathrm{C}$ and is connected with decomposition of organic ingredients.

The changes of FTIR-spectra of clay samples treated by $1 \mathrm{M}, 3 \mathrm{M}$ and $6 \mathrm{M} \mathrm{NaOH}$ solution, and by bacteria Ps. fluorescens AM PS11is similar and is connected with change in three main oscillations for both samples:

FTIR-spectra demonstrate that the effect of alkaline on transformation of clay/illite structure is better pronounced as microbiological impact. Both changes chemically and microbiological treated clay FTIR spectra are similar. Figure 4 show of FTIR for clay $\mathrm{L}$ and processed by $\mathrm{NaOH}$ - solution.

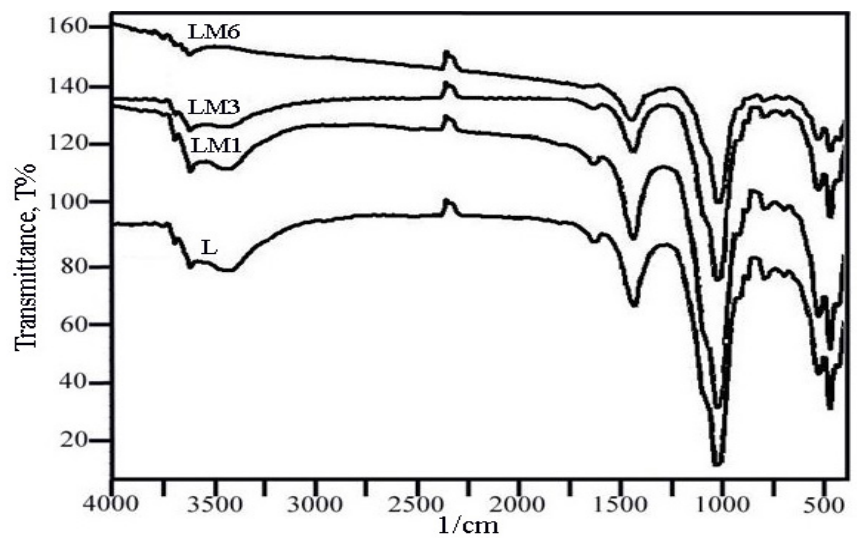

Fig.4. FTIR-spectra of clay $\mathrm{L}$ and treated by $1 \mathrm{M}, 4 \mathrm{M}$ and $6 \mathrm{M} \mathrm{NaOH}$ solutions.

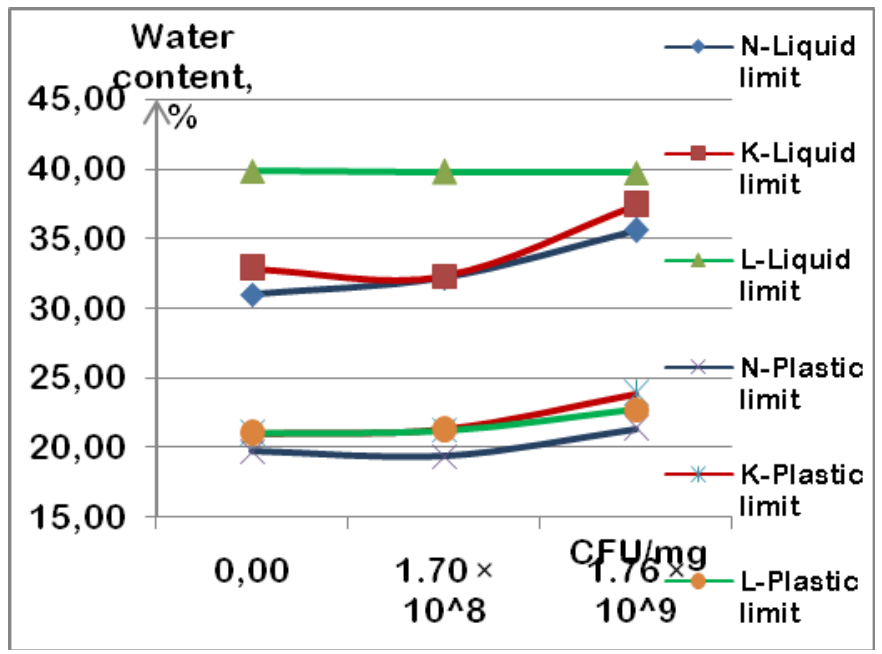

Fig 5. Comparative characterization of plastic and liquid limits of three illite clay samples K, L, N in dependence on bacteria Ps. Fluorescens AM PS11 concentrations.

There can be observedthe change in the oscillationsby:

- OH-stretching bands at $3700-3500 \mathrm{~cm}^{-1}$ connected with oscillations of $\mathrm{OH}^{-}$and water link changes in illite structure

- spectral bands at $1650-1630 \mathrm{~cm}^{-1}$ and $1490 \mathrm{~cm}^{-1}$ typical for changes of oscillations for carbonates,
- strong decreasing Si-O bands at $1050-1000 \mathrm{~cm}^{-1}$,

- 777 and $685 \mathrm{~cm}^{-1}$ showing to insignificant changes of Si$\mathrm{O}-\mathrm{Al}$ oscillations between $\mathrm{SiO}_{4}$ and $\mathrm{AlO}_{6}$ - layer $[10,11]$

which cannot observed for microbiological treated clay.

Regardless of insignificant structure changes of microbiologically treated illite clay that cause visible changes for plastic and liquid limits, as it is shown for three illite clay samples in dependence on concentration of bacteria Ps. Fluorescens AM PS11, Fig.5

\section{B. Characterization of sintered ceramics}

Effect of chemical treatment on compressive strength and porosity development for sintered ceramic samples are shown in the following Figures 6 and 7.

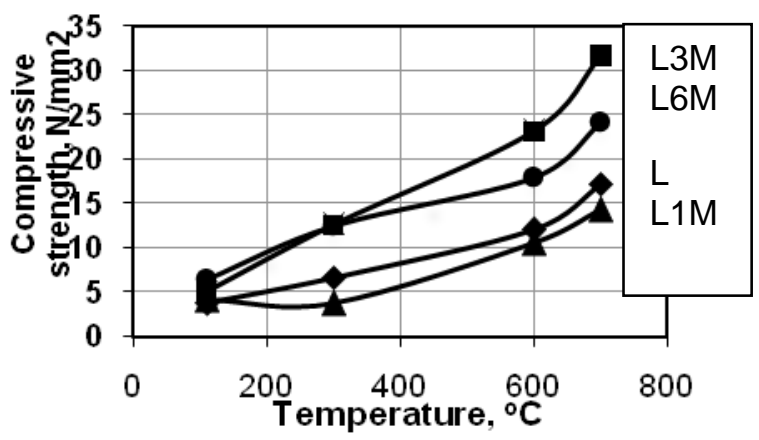

Fig. 6. Compressive strength in dependence on sintering temperature of ceramic samples achieved from differently treated L clay.

There it is important to note on impact of chemically treatment of clay on changes of compressive strength as well as porosity of sintered ceramic samples with an increase of sintering temperature in range of $100{ }^{\circ} \mathrm{C}$ to $700^{\circ} \mathrm{C}$. The compressive strength at sintering temperature $600-700^{\circ} \mathrm{C}$ reaches the value correlated with the same for not chemically treated clay at sintering temperature $950-1000{ }^{\circ} \mathrm{C}$.

As it is shown (figure 7) with growing of molarity of used $\mathrm{NaOH}$ solution pore volume together with pore diameter somewhat decrease. It may mean that grows also amorphous phase. It is shown (Fig. 8) that with the use of chemically treated clay bulk density values decrease.

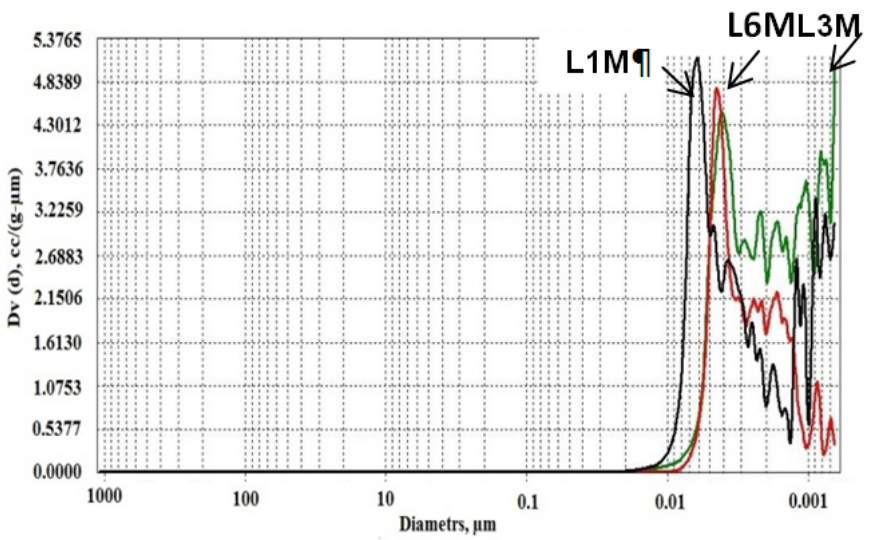

Fig. 7. Porosity development of sintered at $700^{\circ} \mathrm{C}$ ceramic sample L in dependence on molar concentration of $\mathrm{NaOH}$ solutions: $\mathrm{L} 1 \mathrm{M}-$ raw clay $\mathrm{L}$ treated by $1 \mathrm{M} \mathrm{NaOH}, \mathrm{L} 3 \mathrm{M}-$ by $3 \mathrm{M} \mathrm{NaOH}$, L6M-by $6 \mathrm{M}$ $\mathrm{NaOH}$. 


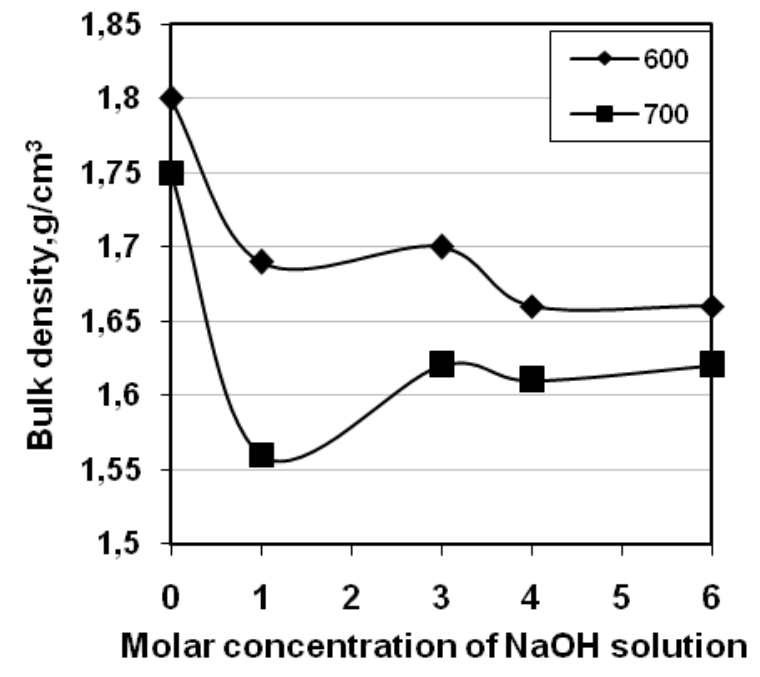

Fig.8. Bulk density of sintered ceramic sample $\mathrm{L}$ in dependence on molar concentration of $\mathrm{NaOH}$ solution.

\section{CONCLUSIONS}

Alkaline and microbiological activation with (accordingly) a sodium hydroxide and bacteria Ps. fluorescens AM PS11of $2: 1$ of not dehydroxylated layered alumosilicate - illite clay has been studied.

This study shows that alkaline activation of illite clay by sodium hydroxide of different concentration at room temperature leads to the slight structural changes mainly characterized by water link changes on FTIR in illite structure together with the decrease of diffraction peaks of all crystalline phases on XRD including illite and kaolinite and with illite structural water losses characterized by DTA.

It is shown that the effect of treatment of illite clay by bacteria on structure changes of illite is small and mainly is expressed on DTA as a decomposition of organic components at $330-360^{\circ} \mathrm{C}$.

The influence of chemically treatment on changes of total porosity and bulk density as well as the increase of compressive strength on sintered ceramic samples is notable. The effect of bacteria mainly is influenced on rheology of the treated clay i.e., plasticity (liquid and plastic limits).

\section{REFERENCES}

[1] Stinkule, A., Stinkulis, G., Blake, D. Composition, distribution and origin of refractory and high-melting clays of Latvia. Scientific Proceedings of the Riga Technical University. Material Science and Applied Chemistry. 2009,Vol. 19, pp. 60-68 (in Latvian).

[2] Stinkulis, G. Mineral deposits of Latvia for production of building materials. Scientific Proceedings of the Riga Technical University. Material Science and Applied Chemistry. 2006, Vol. 13, p. 145-153 (in Latvian).

[3] Ferrari, S., Gualtieri, AF. The use of illitic clays in the production of stoneware ceramics.Applied Clay Science.2006, 32 (1-2), 73-81. http://dx.doi.org/10.1016/j.clay.2005.10.001
[4] Palomo, A., Grutzeck, M.W.,Blanco, M.T. Alkali-activated fly ashes a cement for future. Cement Concrete.Res.,1999, 29 (8), p. 1323 - 1329. http://dx.doi.org/10.1016/S0008-8846(98)00243-9

[5] Duxson, P.,Grant C., Lukey G. C., et.al. The thermal evolution of metakaolingeopolymers: Part 2-Phase stability and structural development. J. Non-Cryst.Solids, 2007, 353, p. 2186-2200. http://dx.doi.org/10.1016/j.jnoncrysol.2007.02.050

[6] Mac Kenzie, K.J.D., Brew, D.R.M., Fletcher, R.A.et.al. Formation of alumosilicategeopolymers from 1:1 layer-lattice minerals pre-treated by various methods: a comparative study. J. Mater. Sci. 2007,42,4667-4674. http://dx.doi.org/10.1007/s10853-006-0173-x

[7] Mac Kenzie, K.J.D., Meinhold , R. H., Brown,et.al.Thermal reactions of pyrophillite studied by high-resolutions solid-state ${ }^{27} \mathrm{Al}$ and ${ }^{29} \mathrm{Si}$ nuclear magnetic resonance spectroscopy.J.Am.Ceram.Soc.,1985, 68,p.266-272. http://dx.doi.org/10.1111/j.1151-2916.1985.tb15320.x

[8] Buhwald A., Hohman M., Posernet.al ,Brendler E. The suitabillity of thermally activated illite/smectite clay as raw material for geopolymer binders.Applied Clay Science, 2009, 46, 300-304. http://dx.doi.org/10.1016/j.clay.2009.08.026

[9] Segliņš, V., Sedmale, G. Latvijas minerālās izejvielas: īpašǐbu apkopojums. RTU Zinātniskie raksti. Materiālzinātne un lietišķā ķīmija. 20011, 24 sēj., Nr.1, lpp. 116-135.

[10] Plusnina I. I., 1967. IR-spectra of Silicate, University of Moscow, p. 45105. (in Russian).

[11] Tenorio Arvide, M.G., et.al., 2008. SmectiteAdorbtion of Aflatoxin Octahedral Composition as Indicated by FTIR.Clays and Clay Minerals. $56,5,571-578$.

Gaida Sedmale, Dr.habil.chem, Assoc.prof./Leading researcher, author of more than 200 scientific publications in the branch of glass and ceramic chemistry and technology. The main outputs of glassy and ceramic materials are protected by more than 50 Latvian and Russian patents. During 20 years her scientific interests have been connected with the new high-temperature and traditional ceramic materials. She delivers the lecture course "Chemistry and Technology of Fine Ceramics" for bachelor and master degree students. Address: Azenes Str.14/24, LV 1048, Riga Latvia Phone: +37167089257 , Fax: +37167615765

e-mail: gsedmale@ktf.rtu.lv

Arturs Korovkins, is a Master of Chemical Technology programme student at Riga Technical University. His scientific interests are connected with the technology and chemistry of ceramic, as well as with glass. He actively participates in presentating his own scientific research results in local and international conferences. Author of about 5 research papers.

Olga Muter, Dr.biol., Leading Researcher at the Institute of Microbiology and Biotechnology, University of Latvia. Her scientific intersts are in the field ot enviromental microbiology and biotechnology. She is experienced in the field of biosorption of havy metals, biodegradation of aromatic contaminats, eco-toxicological assessment of contaminated soil/water. She is the author of more than 30 research papers.

Ingunda Sperberga, Dr.sc.ing., assoc.prof. The author of more than 80 publications including 6 monographs and textbooks concerning crystallography, mineralogy, mineral raw materials of Latvia and physical chemistry of silicates

Address: Azenes Str.14/24, LV 1048, Riga Latvia

Phone: +37167089266 , Fax: +37167615765

e-mail: sperberga@ktf.rtu.lv

Maris Rundans Doctoral student at Riga Technical University, Faculty of Material Science and Applied Chemistry. Author of about 10 research papers in the field of silicate materials. His interests include modification and use of natural raw materials for the development of ceramic products.

Gaida Sedmale, Artūrs Korovkins, Olga Mutere, Ingunda Šperberga, Māris Rundāns. Dažādi apstrādātu illītu mālu struktūras izmaiņas un to ietekme uz keramikas materiāla īpašībām.

Darba mērḳis ir parādīt tipisko 2:1 mālu minerālu/mālu - illītu gan struktūras, gan īpašību izmaiņas, pakḷaujot tos ķīmiskai vai mikrobioloǵiskai iedarbei, lai ,vājinātu vai sagrautu ” illītu struktūru, un noteiktu to ietekmi uz keramikas produkta saķepšanu un raksturīgām īpašībām. Sajā aspektā ir izvēlēti Latvijas 3 atradņu - Lažas, Kupravas un Nīcgales māli, kas atšķiras illītu saturu un līdz ar to arī ar ķ̄imisko 
sastāvu. Ķ̄īmiskai iedarbei (pielietojot dažādas molaritātes $\mathrm{NaOH}$ ) galvenokārt ir izmantoti Lažas atradnes māli, mikrobiologiiskai (pielietojot baktērijas Ps. fluorescens AM PS11) - galvenokārt Kupravas un Nīcgales māli,

Ir pielietotas mūsdienu struktūras un fāžu sastāva, kā arī to izmaiņas ar temperatūru, pētīšanas metodes (FTIR, XRD, DTA). Raksturīgās keramikas īpašības, kā porozitāte, šķietamais blīvums un spiedes pretestība ir noteikti saskaņā ar EN. Mālu reolog̣iskās īpašības pēc mikrobiologiskas apstrādes ir raksturotas ar plasticitātes mērījumiem pēc Aterberga, nosakot plasticitātes augšējo (plūstamības) un apakšējo (sagrūšanas) robežu.

Ir parādīts, ka illītu mālu apstrāde ar dažādas koncentrācijas $\mathrm{NaOH}$ šçīdumu izmaina illītu struktūrā $\mathrm{OH}$-un $\mathrm{H}_{2} \mathrm{O}$ svārstības, tādējādi „vājinot”illîtu struktūru, kas ietekmē attiecīgo keramikas materiālu saķepšanas temperatūru, kā arī raksturīgās keramikas īpašibas un spiedes pretestības lielumu. Būtisks ir spiedes pretestības pieaugums $600-700^{\circ} \mathrm{C}$ temperatūrā saķepinātiem paraugiem līdz $25-30 \mathrm{~N} / \mathrm{mm}^{2}$ salīdzinājumā ar šo lielumu keramikas paraugiem, kas apdedzināti $950-1000^{\circ} \mathrm{C}$ temperatūrā. Noteikts, ka mālu priekšapstrādes ietekme ar bakterijām ir niecīga un galvenokārt novērojama DTA līknēs pie $\sim 330^{\circ} \mathrm{C}$ kā eksotermisks efekts. Šì apstrāde izmaina, it sevišḳi mazāk plastisku mālu, reologiskās īpašības - plūstamību, plasticitāti.

Гайда Седмале, Артурс Коровкинс, Олга Мутер, Ингунда Шперберга, Марис Рунданс. Влияние обработки на изменение структуры и свойств иллитовых глин и керамических материалов.

Цель работы заключается в модифицировании структуры типичных 2:1 глинистых минералов - иллитов путем химической и микробиологической (с применением бактерий Ps. fluorescens AM PS11) обработки для установления влияния изменений структуры и, следовательно, спекаемости керамического материала и характерных свойств. В этом аспекте исследованы три типичные глины Латвии (месторождений Лажа, Куправа и Ницгале), которые отличаются содержанием глинистых минералов - иллитов и также химическим составом. В основном химической обработке подвергнуты глины месторождения Лажа и микробиологической месторождений Куправа и Ницгале.

Применены современные методы исследований структуры и фазового состава и также изменения с температурой (FTIR, XRD, DTA). Определены спекаемость и характерные керамические свойства полученной керамики. Реологические свойства (текучесть разрушение) установлены с использованием метода Атерберга. Керамичеслие свойства определены согласно Европейским нормам. Показано, что химическая обработка щелочным $\mathrm{NaOH}-$ раствором разной концентрации приводит к равномерным изменениям структуры иллитов, связанных с колебаниям связей $\mathrm{OH}-$ и в молекуле $\mathrm{H}_{2} \mathrm{O}$, таким образом «ослабляя» структуру иллитов. Эти изменения приводят к очевидным изменениям спекаемости соответствующего керамического материала и, следовательно, свойств, в том числе сопротивление к сжатию. Следует отметить на относительно высокие значения для сопротивления на сжатие, достигащие для спеченых/ обоженных образцов при $600-700^{0} \mathrm{C}$ значения $25-30 \mathrm{~N} / \mathrm{mm}^{2}$. Определено, что обработка исходной глины бактериям Рs. fluorescens AM PS11 в основном влияет на реологические свойства глины, но в меньшей степени на свойства обожженной керамики. 